\title{
THE SITE OF TIGRANOKERTA: STATUS QUAESTIONIS*
}

\begin{abstract}
Summary: This paper gives an overview of all major identifications of the site of Tigranokerta, the famous foundation of the Armenian king, Tigranes II (the Great, ca. 95-55 BCE). Firstly, the paper presents ancient literary evidence; secondly, it discusses all major locations of Tigranokerta suggested to date (Siirt, Silvan, Arzan, Diyarbakır, Tell Abad, and Kızıltepe); and finally it reaches its own conclusions. It appears that in the current state of research, it is Arzan which is the most likely candidate for the site of Tigranes II's new capital. The paper also engages with the latest archaeological excavations in the Nagorno-Karabakh Republic, and takes issue with the identification of the site near Shahbulagh as the foundation of Tigranes the Great.
\end{abstract}

Key words: Tigranokerta, Armenia, Parthia, Tigranes the Great, Mesopotamia, Arzan, Strabo, Tacitus

\section{INTRODUCTION}

As late as 1903, the eminent British historian Bernard W. Henderson called the identification of Tigranokerta "the time-worn controversy". 'However, since Henderson used those words, much has been written about the location of Tigranokerta, the famous foundation of perhaps the greatest Armenian king ever, Tigranes II (ca. 95-55 BCE), also known as Tigranes the Great. ${ }^{2}$ Many scholars have concluded that without proper

* This paper is part of my research project financed by the National Science Centre in Poland (UMO-2011/03/N/HS3/01159). The project (devoted to three regna minora of Northern Mesopotamia - Sophene, Gordyene and Adiabene) is being conducted at the University of Rzeszów under the supervision of Prof. M. J. Olbrycht.

${ }^{1}$ Henderson, B. W.: Controversies in Armenian Topography I: The Site of Tigranocerta. Journal of Philology 28 (1901) 99-121, here 99.

${ }^{2}$ More recent overviews offering a discussion of a wide range of scholarly opinions include ChaumonT, M.-L.: Tigranocerte: données du problème et état des recherches. ReArm 16 (1982) 89-110; 
archaeological excavation it would be impossible to have a final say on the matter. ${ }^{3}$ Remarkably, Armenian archaeologists began excavations in 2005 near Shahbulagh that have revealed a massive Hellenistic foundation. ${ }^{4}$ According to the main excavator, H. Petrosyan, the newly unearthed structure can be identified as Tigranokerta built by Tigranes the Great (Tigranes II). ${ }^{5}$ Whether or not Petrosyan's identification is correct, these excavations are of paramount significance, as this is actually the first time that archaeological research has gone further than field surveys. This important breakthrough provides us a good opportunity to look afresh at "the time-worn controversy" of the identification of Tigranokerta.

\title{
THE TESTIMONY OF ANCIENT SOURCES
}

The earliest writer to mention Tigranokerta is Strabo (64 or 63 BCE - ca. $24 \mathrm{CE}$ ). ${ }^{6}$ Strabo's references to Tigranokerta are scattered throughout his work $(11.12 .4 ; 11.14$.

\begin{abstract}
Avdoyan, L.: Tigranocerta: The City "Built by Tigranes". In Hovannisian, R. G. (ed.): Armenian Tigranakert/Diarbekir and Edessa/Urfa [UCLA Armenian History and Culture Series 6]. Costa Mesa, California 2006, 81-95; HAKOBYAN, H.: L'Arménie d'une mer à l'autre. In DONABÉDIAN, P. - MUTAFIAN, C. (eds.): Les douze capitales d'Arménie: [exposition présentée à la Maison arménienne de la jeunesse et de la culture de Marseille, du 4 mars au 4 mai 2010]. Paris 2010, 97-104; PLONTKE-LÜNING, A.: Tigranocerta. In DNP (Brill online edition 2012); Holmes' paper (HOLMES, T. R.: Tigranocerta. JRS 7 [1917] 120-138; incorporated into his book published 1923 [HOLMES, T. R.: The Roman Republic and the Founder of the Empire. Oxford 1923]), which was very critical and open to different possibilities, is also worthy of recommendation despite the passage of time.

${ }^{3}$ DillemanN, L.: Haute Mésopotamie orientale et pays adjacents. Contribution à la géographie historique de la région du $V^{\mathrm{e}}$ siècle avant l'ère chrétienne au VI siècle de cette ère. Paris 1962, 271; SINCLAIR, T. A.: The Site of Tigranocerta II. ReArm 26 (1996-1997) 51-118, here 110-111.

${ }^{4}$ To recall just a few more extensive treatments of the problem: ECKHARDT, K.: Die armenischen Feldzüge des Lukullus. Klio 9 (1909) 400-412; HolmES: Tigranocerta (n. 2); HoLMES: The Roman Republic (n. 2); LeHMANN-HAuPT, C. F.: Tigranokerta. In RE VI.1 (1936) 981-1007; DilleMANN (n. 3) 247-272; CHAUMONT: Tigranocerte (n. 2); HEWSEN, R. H.: Introduction to Armenian Historical Geography III: The Boundaries of Orontid Armenia. REArm 18 (1984) 347-366, here 360; HEwSEN, R. H.: Introduction to Armenian Historical Geography IV: The Boundaries of Artaxiad Armenia. REArm 19 (1985) 55-84, here 75-78; CHAUMONT, M.-L.: Quelques notes concernant Tigranocerte. ReArm 21 (1988-89) 233-249; SyME, R.: Sophene and Gordyene. In SyME R. (ed.): Anatolica: Studies in Strabo. Oxford 1995, 51-57; SINCLAIR, T. A.: The Site of Tigranocerta I. ReArm 25 (1994-1995) 183-254; SINCLAIR: Tigranocerta II (n. 3); TRAINA, G.: Strabone e le città dell'Armenia. In TrAINA, G. (ed.): Studi sull'XI libro dei Geographika di Strabone. Con la collaborazione di Alessio Antonio De Siena e Bernadette Tisé. Lecce 2001, 141-154, here 150-154; Avdoyan (n. 2); Petrosyan, H.: Tigranakert in Artsakh. Archaeological Expedition of Artsakh. In PETROSYAN, H. (ed.): Tigranes the Great. Image of Tigranes the Great in Armenian and World Literature and Art. Yerevan 2010, 380-387 and PETROSYAN, H.: La Tigranakert d'Artsakh. In DONABÉDIAN, P. - MutAFIAN, C. (eds.): Les douze capitales d'Arménie. Exposition présentée à la Maison arménienne de la jeunesse et de la culture de Marseille, du 4 mars au 4 mai 2010. Paris 2010, 105-109; TRAINA, G.: Capitales ou résidences royales. La ville dans l'Arménie ancienne. DonabÉdian-MutAfian (n. 2) 45-49; HAKOBYAN (n. 2); PlontKe-LÜNing (n. 2).

${ }_{6}^{5}$ See Petrosyan: Tigranakert (n. 4); PETROSYAN: La Tigranakert (n. 4).

${ }^{6}$ ROMM, J.: Strabo. In BRIGGS, W. W. (ed.): Ancient Greek Authors. Detroit-WashingtonLondon 1997, 359-362. Strabo is believed to have finished his work shortly before his death, which occurred in ca. $24 \mathrm{CE}$. Yet, he also used older sources: he could have had access to works of historians who
\end{abstract}


15; 12. 2. 9; 16. 1. 23). ${ }^{7}$ First, describing the Tauros mountain range in Geog. 11. 12. 4 Strabo says that "the mountains ... on the south, on the far side of the Euphrates, in their extent towards the east from Kappadokia and Kommagene, are, at their beginning, called Tauros proper, which separates Sophene and the rest of Armenia from Mesopotamia; by some, however, these are called the Gordyaean Mountains, and among these belongs also Masion, the mountain which is situated above Nisibis and Tigranokerta." ${ }^{8}$

In 11. 14. 15, Strabo encapsulates the story of Tigranes the Great: listing his greatest achievements, but also his defeat by the Romans. It is in this context that Strabo recalls the foundation of Tigranokerta: "He also founded a city near Iberia, between this place and the Zeugma on the Euphrates; and, having gathered peoples thither from twelve Greek cities which he had laid waste, he named it Tigranokerta; but Lucullus, who had waged war against Mithridates, arrived before Tigranes finished his undertaking and not only dismissed the inhabitants to their several homelands but also attacked and pulled down the city, which was still only half finished, and left it a small village."

In describing the Mazakeni (a people settled between Kappadokia and Pontos; the city of Kaisareia was later established on their territory ${ }^{10}$ ), Strabo writes in 12. 2.9 that Tigranes the Great, after his conquest of Kappadokia, "forced them, one and all, to migrate into Mesopotamia; and it was mostly with these that he settled Tigranokerta. But later, after the capture of Tigranokerta, those who could returned home". ${ }^{11}$

Strabo's 16. 1. 23 is in turn devoted to the description of Mygdonia: "in their country lies Nisibis, which is also called Mygdonian Antiocheia; it lies at the foot of

\footnotetext{
personally took part in Roman campaigns under Pompey and Corbulo (Archias and Theophanes of Mytilene). What is more, he is also known for using valuable, but now lost, works of Apollodoros of Artemita (flourished between 130 and $87 \mathrm{BCE}$ or even into the second part of the 1st century BCE) and Poseidonios of Apamea (ca. $135 \mathrm{BCE}$ - ca. $51 \mathrm{BCE}$ ). It also seems that his personal experience could be of some importance. First, he came from Amaseia in Pontos, which is not far from the region of our interest. Secondly, he also travelled a lot (for instance, the region of Cappadocia was known to him through travel). See Strabon, Géographie, t. VIII, livre XI. Texte établi et trad. par F. LASSERRE. Paris 1975, 13-15; Chaumont: Tigranocerte (n. 2) 91; ChaumonT, M. L.: Apollodorus of Artimita. EncIr 2 (1987) 160161; DrIJVERS, J. W.: Strabo on Parthia and the Parthians. In WIESEHÖFER, J. (ed.): Das Partherreich und seine Zeugnisse: Beiträge des internationalen Colloquiums, Eutin (27.-30. Juni 1996). Stuttgart 1998, 279-293, here 281-282.

${ }^{7}$ The translation of H. L. Jones is quoted here (cf. JONES, H. L.: The Geography of Strabo. With an English Translation. Vol. V, Books X-XII [LCL]. Cambridge, Mass. - London 1928; JONES, H. L.: The Geography of Strabo. With an English Translation. Vol. VII, Books XV-XVI [LCL]. Cambridge, Mass. London 1930. However, readings of proper names are sometimes corrected by the author in the text of the citations to reflect more original forms. In the case of Strabo, the editions of S. Radt (RADT, S.: Strabons Geographika. Bd. 3: Buch IX-XIII. Text und Übersetzung. Göttingen 2004; RADT, S.: Strabons Geographika. Bd. 4: Buch XIV-XVII. Text und Übersetzung, Göttingen 2005; RADT, S.: Strabons Geographika. Bd. 7: Buch IX-XIII. Kommentar. Göttingen 2008; RADT, S.: Strabons Geographika. Bd. 8: Buch XIV-XVII. Kommentar. Göttingen 2009) and LASSERRE (n. 6) were also consulted.

${ }^{8}$ JONES: Strabo, vol. V (n. 7) 298-299.

9 JONES: Strabo, vol. V. (n. 7) 336-337.

${ }^{10}$ LehmanN-HAuPT: Tigranocerta (n. 4) 982; Dillemann (n. 3) 250; CHAUMONT: Tigranocerte (n. 2) 90

${ }^{11}$ JONES: Strabo, vol. V. (n. 7) 366-367.
} 
Mt. Masion, and so do Tigranokerta and the regions of Karrhae and Nikephorion, and Chordiraza and Sinnaka, in which last Crassus was slain...". ${ }^{12}$

Tigranokerta also comes to the fore in Plutarch's narrative about Lucullus' campaign against Tigranes the Great. ${ }^{13}$ Plutarch's (ca. 45-120 CE) Vitae Parallelae includes a narrative about Lucullus, which though written in the 2 nd century CE, is believed to have been based on the (now lost) personal contribution of Archias; Archias personally accompanied Lucullus during the Mithridatic campaign. ${ }^{14}$ The primary purpose of Lucullus' campaign in 69 BCE was to capture Tigranokerta. Generally speaking, the geographical and topographical data from Plutarch's text can be summarized in three points. ${ }^{15}$ Firstly, Lucullus' troops crossed the Euphrates, traversed Sophene, and finally, by crossing the Tigris, "entered Armenia". At some point during the march through Sophene, Lucullus pointed to the distant range of the Tauros and said to his soldiers: "Yonder lies the fortress which we must rather bring low" (Luc. 24. 8). ${ }^{16}$ It follows that Tigranokerta was located east of Sophene (whose border was marked by the Tigris) and at the foot of the Tauros. Secondly and similarly, having received the message about the Roman advance, Tigranes is said to have withdrawn from Tigranokerta "to the Tauros" to gather reinforcements (Luc. 25. 5). ${ }^{17}$ Thirdly, Plutarch's text offers some topographical details concerning the location of the siege and the battlefield in reference to the city: the Roman camp stood on a great plain ( $\dot{\varepsilon} v \pi \varepsilon \delta i ́ \omega \mu \varepsilon \gamma \alpha \dot{\lambda} \lambda \omega)$ along a river which bent westwards, at which point it was easily fordable (Luc. 27. 3-4). ${ }^{18}$

Just as in Plutarch, Tigranokerta appears in Tacitus' $(55-120 \mathrm{CE})^{19}$ Annales in the context of Roman military campaigns in Armenia. ${ }^{20}$ Firstly, in Ann. 14. 24-25 Tigranokerta is mentioned as one of places that Corbulo's troops passed on their way back from Artaxata; to be more precise, Tigranokerta appears in the following sequence: the Mardi, the Tauronite region ("regio Tauranitium"), Tigranokerta, the military post ("praesidium") of Legerda. ${ }^{21}$ Secondly, we learn in Ann. 15. 4 that part of Tigranokerta's walls were encircled by the Nicephorius, "a river of considerable width" ${ }^{22}$ Thirdly, Ann. 15. 5 speaks of Roman envoys sent to Nisibis to offer an arms

12 JONES: Strabo, vol. VII. (n. 7) 230-231.

${ }^{13}$ The edition of B. Perrin (cf. PERRIN, B.: Plutarch's Lives. With an English Translation. Vol. II [LCL]. Cambridge, Mass. - London 1914) is used here.

${ }^{14}$ SCARDigLI, B.: Die Römerbiographien Plutarchs. München 1979, 121-122.

${ }_{16}^{15}$ ChaumONT: Tigranocerte (n. 2) 92.

${ }^{16}$ PERRIN (n. 13) 548-549.

${ }^{17}$ PERRIN (n. 13) 550-553.

${ }^{18}$ PERRIN (n. 13) 556-559.

${ }^{19}$ DillemanN (n. 3) 252.

${ }^{20}$ The edition of J. Jackson (Tacitus, The Annals. With an English Translation by J. JACKSON. Vol. V, Books XIII-XVI [Loeb Classical Library]. Cambridge, Mass. - London 1937) is used here. The commentaries of H. Furneaux (FurneauX, H.: P. Cornelii Taciti Annalium ab excessu divi Augusti libri = The Annals of Tacitus. Ed. with Introd. and Notes. Vol. II, Books XI-XVI. Oxford 1907) and E. Koestermann (KOESTERMANN, E.: Cornelius Tacitus, Annalen. Bd. III: Buch 11-13. Heidelberg 1967) were also consulted.

${ }^{21}$ JACKSON (n. 20) 146-149.
${ }^{22}$ JACKSON (n. 20) 220-221. 
truce to the Parthian king, Vologaeses, and characterizes Nisibis as "a town thirtyseven miles distant from Tigranokerta". ${ }^{23}$

Important passages concerning both the political significance and the topography of Tigranokerta can be found in Historia Romana of Appian of Alexandria (ca. 95-165 CE). ${ }^{24}$ According to Appian, Tigranokerta was founded in the place where Tigranes "had first assumed the diadem of Armenia" (Mithr. 67). ${ }^{25}$ Appian also gives some details concerning the city and its surroundings. According to him, the city was founded on an ambitious scale (Mithr. 84). It was surrounded with walls 50 cubits high, the base of which was full of stables; in the suburbs, Tigranes also built a pal-

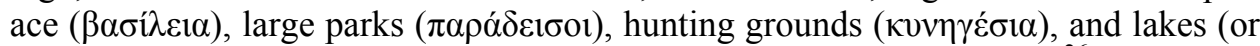

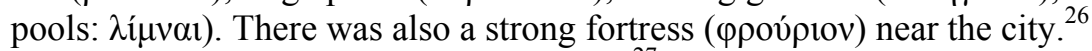

Pliny the Elder's $\left(23 \mathrm{BCE}-79 \mathrm{CE}^{27}\right)$ Historia Naturalis recalls Tigranokerta twice. In Pliny's list of famous cities located in Greater Armenia (HN 6. 26), Tigranokerta is mentioned as a city located on an elevated site (in excelso). ${ }^{28}$ In turn, while discussing the dimensions of Armenia as identified by longitude and latitude, Pliny briefly remarks in $H N$ 6. 27 that, according to Julius Caesar, the latitude of Armenia is calculated from Iberia to Tigranokerta. ${ }^{29}$

Ptolemy (90-168 CE) ${ }^{30}$ also mentions Tigranokerta in his list of cities in the territory to the east of the sources of the Tigris (Ptol. 5. 13. 20-21). ${ }^{31}$ This territory encompassed the following countries and peoples: Bagrauanende, Godyene, Kotaia, and the Mardians (Ptol. 5. 13. 20). Tigranokerta is listed between Pherendis and Sardeva and placed at $76^{\circ} 45^{\prime}-39^{\circ} 40^{\prime}$ (Ptol. 5. 13. 21). ${ }^{32}$

Important references to Tigranokerta can also be found in Late Roman sources. Parthica of Asinius Quadratus (who flourished in the first half of the 3rd century $\mathrm{CE}^{33}$ ) is not extant; according to the 6th-century-CE Stephanus Byzantinus, however, Asinius

${ }^{23}$ JACKSON (n. 20) 222-223.

${ }^{24}$ WHITE, H.: Appian's Roman history. With an English transl. Vol. II: Book VIII, part II-Book XII [LCL] Cambridge, Mass. - London 1912, VII.

${ }^{25}$ WHITE (n. 24) 364-365.

${ }^{26}$ WHITE (n. 24) 398-399.

${ }^{27}$ Keyser, P. T.: Pliny the Elder. In Briggs, W. W. (ed.): Ancient Roman Writers. Detroit-Washington-London 1999, 235-242.

${ }^{28}$ RACKHAM, H.: Pliny, Natural History. With an English Translation. Vol. II: Books III-VII [LCL]. Cambridge, Mass. - London 1942, 356-357.

${ }^{29}$ RACKHAM (n. 28) 356-357.

${ }^{30}$ Berggren, J. L. - Jones, A.: Ptolemy's Geography: An Annotated Translation of the Theoretical Chapters, Princeton 2000, 23-24.

31 The edition used here is that of StüCKELBerger, A. - GrAsshoff, G.: Klaudios Ptolemaios, Handbuch der Geographie. Griechisch-Deutsch. Basel 2006.

${ }^{32}$ According to STÜCKELBERGER-GRASSHOFF (n. 31) 554-555. Likewise HewSEN, R. H.: Ptolemy's Chapter on Armenia. An Investigation of his Toponyms. REArm 16 (1982) 111-150, here 137. By contrast, Chaumont suggests a different location $-76^{\circ} 45^{\prime}-30^{\circ} 40^{\prime}$. This is apparently a mistaken interpretation of the Greek coordinates: $0 \varsigma^{\circ} \mathrm{L} \delta^{\prime} \lambda \theta^{\circ} \gamma \mathrm{o}^{\prime}$ (the same reading can be found in both STÜCKELBERGER-GRASSHOFF (n. 31) 554-555 and NobBE, C. F. A.: Claudii Ptolemaei Geographia. Editio stereotypa. Vol. II. Leipzig 1845, 55).

${ }^{33}$ ChaumONT: Tigranocerte (n. 2) 93. 


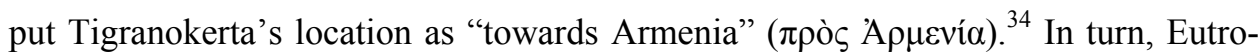
pius (who flourished during the latter half of the 4th century CE) in his Breviarium 6. 9. 1 (a summary of the Roman history ab urbe condita based mainly on Livy) ${ }^{35}$ recalls Lucullus' capture of Tigranocerta and calls it civitas Arzanenae nobilissima, regni Armeniaci. ${ }^{36}$

Tigranokerta is also known to Roman itineraries: the Tabula Peutingeriana (hereinafter TP) and the Ravennatis Anonymi Cosmographia (also known as Ravenna Cosmography or Anonym of Ravenna, and abbreviated as $R A) .{ }^{37}$ The $T P$ is in fact a medieval copy (12th/13th centuries) of a map-like representation of the ancient world (as known to the Romans). However, it is believed to be based on an ancient model, which took its final shape in the 4th century CE (but whose sources must have been older, perhaps going back to the 1 st century $\mathrm{CE}) .{ }^{38}$ In turn, $R A$ is considered to be the 8th-century-CE work of an anonymous writer who lived in Ravenna (see $R A$ 4. 31). ${ }^{39}$ First, it should be noted that in the $T P$, being a visual presentation, Tigranokerta is placed above the Tigris, i.e., definitely north of this river. Furthermore, in $T P 11.3$, Tigranokerta is presented at the crossroads of three routes: from ad Tygrem to Tigranokerta (lit. Triganocartem); from Tigranokerta (via Sardebar) to Singara; and from Tigranokerta (via Raugonia) to Artaxata. ${ }^{40}$ In turn, Tigranokerta is mentioned twice in RA: between Dizanas and Caspi in the list of cities in Parthia $(R A 2.4)^{41}$ as well as in the list of cities of Media Minor between Zancerion and Colchanam $(R A 2.10)^{42}$

Several references to Tigranokerta can be found in Armenian sources. The oldest is the Epic Histories 4. 24 (abbreviated hereinafter as BP [Buzandaran patmut'iwnk']), which describes 4th-century-CE Armenia, but which was created by an anonymous cleric probably in the 5th century CE. ${ }^{43}$ BP 4.24 tells of the Persian invasion led by King Shapur into Armenia during the reign of the Armenian king Aršak II $(350$ - ca. 364/367 CE). It lists the territories through which the Persian

${ }^{34}$ MeINEKE, A.: Stephani Byzantii Ethnicorum quae supersunt. Vol. 1. Berlin 1849, 623.

${ }^{35}$ Chaumont: Tigranocerte (n. 2) 93.

${ }^{36}$ MÜLLER, F. L.: Eutropii Breviarium ab urbe condita = Eutropius, Kurze Geschichte Roms seit Gründung (753 v. Chr.-364 n. Chr.). Einleitung, Text und Übers., Anmerkungen, Index Nominum (a: geographicorum, b: historicorum). Stuttgart 1995, 84.

${ }^{37}$ For basic information on both sources, see HEwSEN, R. H.: Armenia. A Historical Atlas. LondonChicago 2001, 64-65; Fellmeth, U.: Tabula Peutingeriana. In DNP (Brill online edition) 2013; BRODERSEN, K.: Geographus Ravennas. In DNP (Brill online edition) 2013.

${ }^{38}$ FELLMETH (n. 37).

${ }^{39}$ BRODERSEN (n. 37).

${ }^{40}$ See Miller, K.: Itineraria Romana: römische Reisewege an der Hand der Tabula Peutingeriana. Stuttgart 1916, 745-747; HEWSEN: Armenia (n. 37) m. 58.

${ }^{41}$ SCHNETZ, J.: Itineraria Antonini Augusti et Burdigalense. Vol. II: Ravennatis anonymi Cosmographia et Guidonis Geographica. Leipzig 1940, 17.

${ }^{42}$ SCHNETZ (n. 41) 21.

${ }^{43}$ GarsoÏAn, N. G.: The Epic Histories Attributed to P'awstos Buzand (Buzandaran Patmut 'iwnk'). Translation and Commentary. Cambridge, Mass. 1989, 1-22; ANDREws, T. L.: P'awstos Buzand in DNP (Brill online edition) 2012; HANNICK, CH.: Faustus of Byzantium in DNP (Brill online edition) 2012. 
army moved as well as cities and fortresses captured by the Persians. In this context, Tigranokerta is mentioned as a great city located in the Ałjnik' district. ${ }^{44}$ Tigranokerta in the land of Ałjnik' is mentioned again as the place of the missionary activity of St. Epip'an, who built a martyrium there (BP 27). ${ }^{45}$

Tigranokerta also appears in Moses Khorenats'i's (abbreviated hereinafter as $M X$ ) History of the Armenians (who writes about 5th century CE Armenia, but the dating of this work is controversial and varies from the 5 th century to the 9th century $\mathrm{CE})^{46}$ who recalls it twice in his work. In describing the reign of Tigranes the Great, $M X 1.30$ writes that the king settled his royal sister Tigranuhi in Tigranokerta. ${ }^{47}$ This passage does not include any geographical or topographical details. In turn, $M X 3.26-28$ is devoted to the siege and capture of Tigranokerta by the Persian army under King Shapur. ${ }^{48}$ Moses' description features many parallels with Ammianus Marcellinus' description of the Persian capture of Amida in 359 CE (Amm. Marc. 19. 1-8). ${ }^{49}$ Hence, it follows that to Moses Roman Amida was located on the site of Hellenistic Tigranokerta. $^{50}$

The same identification of Tigranokerta can be found in two other Armenian sources: the History of Vardan and the Armenian War attributed to Elishe and in the chronicle of Matthew of Edessa. ${ }^{51}$ The work attributed to Elishē is devoted to the Armenian uprising against the Sassanid kingdom in 450/451 CE, but was likely written in the 6th century CE. ${ }^{52}$ Elishe speaks of the foundation of Edessa by King Abgar and compares it with Tigranes' foundation of "Tigranokerta [nowadays] called Amit".,53 Likewise, the 12th-century-CE chronicle of Matthew of Edessa mentions "the town of Tigranokerta, which is also named Amida, situated on the Tigris River". 54

Tigranokerta is also recalled in the context of the military campaign of Emperor Heraclius against the Sasanians in 622-628 CE by two other Armenian sources: Sebēos (7th century CE) and Stephen of Tarōn (known also as Asołik or Asołnik,

${ }^{44}$ GARSOÏAN: The Epic Histories (n. 43) 157.

${ }^{45}$ GARSOÏAN: The Epic Histories (n. 43) 207.

${ }^{46}$ See TrainA, G.: Armenische Quellen. In HACKL, U. - JACOBS, B. - WeBER, D. (eds.): Quellen zur Geschichte des Partherreiches: Textsammlung mit Übersetzungen und Kommentaren. Bd. 3: Keilschriftliche Texte, Aramäische Texte, Armenische Texte, Arabische Texte, Chinesische Texte [Novum Testamentum et Orbis Antiquus 85]. Göttingen 2010, 402-454, here 417-419.

${ }^{47}$ ThOMsON, R. W.: Moses Khorenats $i$ : History of the Armenians. Translation and Commentary. Cambridge, Mass. - London 1978, 119.

${ }^{48}$ THOMSON: History of the Armenians (n. 47) 281-284.

${ }^{49}$ THOMSON: History of the Armenians (n. 47) 281, n. 1.

${ }^{50}$ MARKWART, J.: Südarmenien und die Tigrisquellen nach griechischen und arabischen Geographen [Studien zur armenischen Geschichte, Bd. 4]. Wien 1930, 113-114; DillemanN (n. 3) 257; CHAUMONT: Tigranocerte (n. 2) 100; CHAUMONT: Quelques notes (n. 4) 237; TRAINA: Strabone (n. 4) 151.

${ }^{51}$ CHAUMONT: Quelques notes (n. 4) 237.

${ }^{52}$ SAVVIDIS, K.: Elishē in DNP (Brill online edition) 2012.

${ }^{53}$ ChaumonT: Tigranocerte (n. 2) 100, n. 69.

${ }^{54}$ Dostourian, A. E.: Armenia and the Crusades. Tenth to Twelfth Centuries. The Chronicle of Matthew of Edessa. Lanham - New York - London 1993, 26. 
11 th century CE). ${ }^{55}$ The Roman military operations were at first concentrated in Media, but at some point Heraclius decided to move the theater of war to Iberia and Albania via Ałuank'. His march was, however, stopped by the Persians, who came up against Heraclius' forces in the Gardman province, where both armies are said to have met at "the other Tigranokerta" (Sebēos 38. 125). ${ }^{56}$ The same episode from Heraclius' campaign is also briefly referred to by Stephen of Tarōn in his chronicle (2. 4): on their withdraw from Persia the Romans moved via Media to Phaytakaran in the land of Kasp ${ }^{6} \mathrm{k}^{6}$, where they encamped at Tigranokerta. Afterwards, Heraclius moved to Nahčavan. ${ }^{57}$

As we can see, there are quite a number of ancient sources that provide us with clues concerning the location of Tigranokerta. A few general observations are in order.

First and foremost, although our sources, taken literally, do not agree on one location, they still allow us to distinguish a few groups of sources that feature approximately the same location. It is Strabo in the first place whose writing makes a very clear connection between Tigranokerta and Nisibis; what is more, both cities are said to lie at the foot of Mt. Masion. Tac. Ann. 15. 5 also belongs in this context: the distance between both cities was 37 Roman miles (approximately $55 \mathrm{~km}$ ). ${ }^{58}$ Every distance can be counted a little differently depending on the course of the track, ${ }^{59}$ but, generally speaking, this number suggests a considerable proximity of both sites. Secondly, two other sources, Eutropius 6. 9. 1 and the Armenian Epic Histories, unambiguously point to Arzanene (Ałjnik' in Armenian, the district between the Batman and Bohtan rivers, centered around the city of Arzan) as the location of ancient Tigranokerta. ${ }^{60}$ This location is also suggested by Ptolemy's coordinates. The interpretations of many toponyms in Roman itineraries are uncertain. Generally speaking,

55 ThOmson, R. W. - HowArd -Johnston, J.: The Armenian History Attributed to Sebeos. Transl. with Notes by R. W. Thomson; Historical Commentary by James Howard-Johnston; Assistance from Tim Greenwood. Part I: Translation and Notes. Liverpool 1999, XI-XXX; ESBROECH, M. VAN: Asolik. EncIran 2 (1987) 465-467.

${ }^{56}$ THOMSON-HOWARD-JOHNSTON (n. 55) 82. This passage is differently numbered in MACLER, F.: Histoire d'Héraclius par l'évècque Sebêos. Paris 1904, 82 as Sebēos 26. For the Gardman, see HEWSEN, R. H.: The Geography of Ananias of Šrak: Ašxarhac 'oyc'. The Long and the Short Recensions. Translation and Commentary. Wiesbaden 1992, 261. 1907,84

${ }^{57}$ Gelzer, H. - BurCKHARDT, A.: Des Stephanos von Taron Armenische Geschichte. Leipzig

${ }^{58}$ CHAUMONT: Tigranocerte (n. 2) 92.

${ }^{59}$ See SINCLAIR: Tigranocerta I (n. 4) 219: ancient maps (like TP) usually give straight-line measurements, but in practice tracks do not go in a perfectly straight line.

${ }^{60}$ Manuscripts offer different readings of the key toponym, Arzanene in Eutropius, for instance: Arzianenae, Arzyanenae, Arzianem, Artianem. See RüHL, F.: Eutropi Breviarium ab urbe condita. Leipzig 1909, XIV. Yet, the name of the district, Arzanene is still recognizable despite these small distortions. Dillemann's emendation into Arzamenae, the district around (Tell) Harzem (south of the Tigris and to the northeast of Tell Ermen) is clearly intended for strengthening the case of Tell Ermen as the site of Tigranokerta. In turn, the emendation into Armeniae collides with the presence of regni Armeniaci in the phrase. See DILLEMANN (n. 3) 258-259 (for information, but not the interpretations); CHAUMONT: Tigranocerte (n. 2) 93, n. 32; SINCLAIR: Tigranocerta I (n. 4) 197. 
however, there can be no doubt that in light of this evidence, Tigranokerta was located north (east) of the Tigris. Thirdly, three other Armenian sources - Moses Khorenats' $\mathrm{i}$, Elishē, and Matthew of Edessa - unambiguously understand the late Roman Amida (modern Diyabarkur) as Tigranokerta. Fourthly and finally, the sources describing Emperor Heraclius' campaign (Sebēos, Stephen of Tarōn) locate Tigranokerta along the route from Media to Iberia, and this location can match neither the Nisibis region nor Arzanene. Indeed, Sebēos himself speaks about "the other Tigranokerta". Only the last group of sources does not contain any explicit connection between Tigranokerta and Tigranes the Great.

Furthermore, our sources differ when it comes to the nature of the data provided. Some sources offer relatively precise details about the geographical position or the topographical features of the site of Tigranokerta, while others refer to it indirectly by briefly mentioning it only in relation to other (sometimes well-known but sometimes unidentified) sites. It follows that not every reference has the same importance. In addition to Pliny the Elder, who remarks that Tigranokerta was located on an elevated site (in excelso), the most detailed topographical descriptions of Tigranokerta can be found in ancient reports on sieges and battles near Tigranokerta. We possess three such accounts: Plutarch, Appian, and Tacitus. Plutarch's descriptions of Lucullus' campaign envisage a fortified city at the foot of the Tauros, located on the river, which takes a turn to the west (where it is easily fordable); furthermore, there was a great plain by the river, where the Romans encamped. Appian also gives precise details on the topography of the city and its vicinity: the city had massive walls and the suburbs had a palace, parks, hunting grounds, and lakes (or pools). Additionally, there was a fortress and a hill near the city. Finally, according to Tacitus, Tigranokerta was located on the Nicephorius River, the city featured massive walls, one part of which was protected by the river and another by a huge ditch.

\section{MODERN LOCATIONS}

Just as ancient sources do not really agree on the location of Tigranokerta, so modern scholars cannot agree either, as they too have suggested a number of possible sites that could roughly match the indications provided by ancient sources (see Fig. 1). Following the basic distinction in our evidence between the testimony of Strabo/Tacitus and that of Eutropius/BP/Ptolemy/Roman itineraries, all identifications can be tentatively divided into two groups on geographical grounds - locations south of the Tigris and north of the Tigris. Additionally, attempts to locate Tigranokerta in northeastern Armenia can be listed as a separate group.

The most frequently suggested sites north of the Tigris are Siirt $\left(37^{\circ} 55^{\prime} 40.6^{\prime \prime} \mathrm{N}\right.$, $\left.41^{\circ} 56^{\prime} 32.0^{\prime \prime} \mathrm{E}\right)$, Silvan (Martyropolis [ $\left.38^{\circ} 8^{\prime} 32^{\prime \prime} \mathrm{N}, 41^{\circ} 0^{\prime} 5^{\prime \prime} \mathrm{E}\right]$ ), and Arzan ( $37^{\circ} 58^{\prime}$ $\left.26^{\prime \prime} \mathrm{N}, 41^{\circ} 23^{\prime} 05^{\prime \prime} \mathrm{E}\right)$. 
The identification of Tigranokerta with Siirt was first put forward by J. B. d'Anville $^{61}$ and later accepted by Forbiger ${ }^{62}$ and Egli. ${ }^{63}$ Yet it has never been widely held and nowadays seems to be outdated. The strongest argument in favor of Siirt is Ptolemy, whose coordinates match the location of the province of Arzanene; therefore, Siirt can be considered along with the other sites. ${ }^{64}$ However, two basic facts weigh against this identification. ${ }^{65}$ Firstly, there are no archaeological remains on the ground that could indicate its inhabitation in ancient times, ${ }^{66}$ Siirt has even been suggested to be a modern foundation. ${ }^{67}$ Secondly, topographical features of the modern Siirt and its vicinity do not suit the ancient descriptions well: the modern city is not located directly on a river bank (the Bohtan is located several kilometers away from the city), there is no plain suitable as battlefield, and the riverbanks are too rugged and steep for fording by a large number of people. ${ }^{68}$

Modern Silvan (also known as Martyropolis in Latin, Mayyāfāriqīn in Arabic, and Nep 'rkert in Armenian) has always been a strong candidate for ancient Tigranokerta. This identification has been supported by many scholars and was - until recently - the prevailing opinion. ${ }^{69}$ Essentially, there are three important arguments in its favor. First, Martyropolis is known as a very important city in late Roman and Byzantine times. $^{70}$ It served as the capital of the satrapy (and next, the district) of

${ }^{61}$ D’AnVILle, J. B.: Géographie ancienne abrégée. Nouvelle édition. Paris 1769, 119-120.

${ }^{62}$ Forbiger, A.: Handbuch der alten Geographie aus den Quellen. Bd. II: Politische Geographie der Alten: Asia, Africa. Leipzig 1844, 604, n. 55.

${ }^{63}$ EgLI, E.: Feldzüge in Armenien von 41-63 n. Chr. Ein Beitrag zur Kritik des Tacitus. In BüNDIGER, M. (Hrsg.): Untersuchungen zur Römischen Kaisergeschichte. Bd. I. Leipzig 1868, 303-306.

${ }^{64}$ BELCK, W.: Aus den Berichten über die armenische Expedition. Zeitschrift für Ethnologie 31 (1899) 236-280, here 266; CHAUMONT: Tigranocerte (n. 2) 95.

${ }^{65}$ BelcK (n. 64) 266; CHAUMONT: Tigranocerte (n. 2) 95.

${ }^{66}$ But see TAYLOR, J. G.: Travels in Kurdistan, with Notices of the Sources of the Eastern and Western Tigris, and Ancient Ruins in Their Neighbourhood. Journal of the Royal Geographical Society of London 35 (1865) 21-58, here 30-31 and HoLMES: The Roman Republic (n. 2) 418, who suggest that ancient remains could be beneath the modern foundation and can therefore only be reached archaeologically.

${ }^{67}$ BELCK (n. 64) 266.

${ }^{68}$ CHAUMONT: Tigranocerte (n. 2) 94-95; Holmes: The Roman Republic (n. 2) 418.

${ }^{69}$ MOLTKE, H. vON: Briefe über Zustände und Begebenheiten in der Türkei aus den Jahren 1835 bis 1839. Berlin 18936 , 302; BELCK (n. 64) 263-275; CHRISTENSEN, A.: L'Iran sous les Sassanides. Copenhague 1944, 239; CARCOPINO, J.: La république romaine de 133 a 44 avant J.-C. P. 2: César. Paris 1950", 581, n. 3; ManANDiAn, H. A.: The Trade and Cities of Armenia in Relation to Ancient World Trade. Translated from the Second Revised Edition by N. G. GARSOÏAN. Lisbon 1965, 62; ADONTZ, N. - GARSOÏAN, N. G.: Armenia in the Period of Justinian: the Political Conditions Based on the "naxarar" System. Transl. with partial revisions by N. G. GARSOÏAN. Lisbon 1970, 376, n. 10, n. 5; MAGIE, D.: Roman Rule in Asia Minor to the End of the Third Century after Christ. Princeton 1950, 1214, n. 36; HEwSEN: Introduction III (n. 4) 360; BIFFI, N.: Il Medio Oriente di Strabone. Libro XVI della Geografia. Introduzione, traduzione e commento. Bari 2002, 165.

${ }^{70}$ Martyropolis owes its Latin name to the following story: in approximately $410 \mathrm{CE}$, bishop Marutha returned from his diplomatic missions to Persia with many relics of martyrs, which he buried in a newly-built church. His efforts were supported by Emperor Theodosius II, who undertook a major expansion and embellishment of this place. This story of the city's foundation does not necessarily mean that there was no previous settlement before Theodosius II. See HoLMES: The Roman Republic (n. 2) 419; SINCLAIR: Tigranocerta I (n. 4) 220-221. 
Sophanene. ${ }^{71}$ Secondly, generally speaking, its geographical and topographical environment fits well ancient data on Lucullus' maneuvers against Tigranes. It is located on the Farqin River, a tributary of the Batman River at the foot of the Tauros; the plateau on which it stands can indeed be described as Pliny's in excelso; and there is a large plain next to the river. ${ }^{72}$ Lastly, Lehmann-Haupt pointed to a Greek inscription placed on stone blocks uncovered from the city walls of Silvan. The inscription speaks of the capture (recovery) of royal dominions (the city called Nekra, which is likely to be understood as Martyropolis known in Armenian as $N p$ 'rkert) by an anonymous king. ${ }^{73}$

Those who have connected Tigranokerta with present-day Arzan include H. Kiepert (only temporarily), ${ }^{74}$ K. Miller, ${ }^{75}$ and E. Herzfeld. ${ }^{76}$ Recently, T. Sinclair came out in its favor and found widespread acceptance. ${ }^{77}$ This identification is sup-

${ }^{71}$ However, supporters of the site of Martyropolis (especially LEHMANN-HAUPT, C. F.: Armenien einst und jetzt: Reisen und Forschungen. Bd. 1: Kaukasus zum Tigris und nach Tigranokerta. Berlin 1910, 407-410; LEHMANN-HAUPT: Tigranocerta [n. 4] 1003-1005) claim that Martyropolis could have belonged to the district of Arzanene temporarily, especially at the time when the narrative of the Epic Histories was composed. This idea is clearly intended for weakening the case of Arzan in favor of that of Martyropolis: acknowledging that Tigranokerta was located in Arzanene would not exclude Martyropolis. However, it should be noted that it was only after $591 \mathrm{CE}$ when the territories of Sophanene and Arzanene were united in one province called Mesopotamia or Armenia Quarta. This status is preserved in the 7th century CE Geography of Ananias of Sirak, which knows of Np̈rkert (meaning the Latin Martyropolis and its surroundings) and locates it in Ałjnik' (Arzanene). By contrast, the Epic Histories were created in the 5th century CE and know Sophanene and Arzanene as separate districts. See HÜBSCHMANN, H.: Die altarmenischen Ortsnamen, Strassburg 1904 (Nachdruck: Amsterdam 1969), 309; HOLMES: The Roman Republic (n. 2) 420-421; CHAumONT: Tigranocerte (n. 2) 96; SINCLAIR: Tigranocerta I (n. 4) 197-198 and 222-223, n. 23.

${ }^{72}$ CHAUMONT: Tigranocerte (n. 2) 96-97; ECKHARDT (n. 4) 405-409; HolmeS: The Roman Republic (n. 2) 419-420; LEHMANN-HAUPT: Armenien (n. 71) 390-392; LEHMANN-HAUPT: Tigranocerta (n. 4) 988-994.

${ }^{73}$ LEHMANN-HAUPT, C. F.: Eine griechische Inschrift aus der Spätzeit Tigranokerta's. Klio 8 (1908) 497-520; LEHMANN-HAUPT: Armenien (n. 71) 410-419, 498-515; LEHMANN-HAUPT: Tigranocerta (n. 4) 1002-1005. What is more, LEHMANN-HAUPT: Armenien (n. 71) 419-420 and LEHMANN-HAUPT: Tigranocerta (n. 4) 1002 point to a monumental rock-cut relief near Boşat ( $90 \mathrm{~km}$ north of Silvan) and understand it as a depiction commemorating Ardashir I's conquest of Armenia. However, the dating of the Boşat relief is disputed, according to M. NOGARET (A propos du relief 'Sassanide' de Boşat en Turquie orientale. Iranica Antiqua 18 [1983] 221-232), it is a Parthian and not a Sasanian relief. Furthermore, its existence well illustrates the importance of the Qulp mountain pass (and only indirectly the importance of Silvan located not far from this pass), but this fact does not automatically impose any specific identification of Silvan. For the Boşat relief, see also SINCLAIR, T. A.: Eastern Turkey: an Architectural and Archaeological Survey. Vol. 3. London 1989, 281; SINCLAIR: Tigranocerta I (n. 4) 232.

${ }^{74}$ KIEPERT, H.: Die Lage von Tigranokerta. Hermes 9 (1875) 139-149, here 142-143.

75 MiLler (n. 40) 744.

${ }^{76}$ Herzfeld, E.: The Persian Empire. Edited from Posthumous Papers by G. WALSER. Wiesbaden 1968, 232. See also Herzfeld's personal communication preserved in GUYER, S.: Reisen in Mesopotamien. Dr. A. Petermanns Mitteilungen aus Justus Perthes' Geographischer Anstalt 62 (1916) 205-210, here 207, n. 2.

${ }^{77}$ Including HEwSEN: Introduction IV (n. 4) 75-78; TRAINA, G.: Teatro greco nell'Armenia antica. In Migliario, E. - TroiANi, L. - ZECCHINI, G. (eds.): Società indigene e cultura grecoromana. Rome 2010, 95-103, here 99; RedGATE, A. E.: The Armenians. London 2000, 84; HewsEN: Armenia (n. 37) 56; COMForT, A. M.: Roads on the Frontier between Rome and Persia: Euphratesia, Osrhoene and Mesopotamia from AD 363 to 602. PhD diss. Exeter 2008, 284. 
ported by the evidence of Eutropius and the Epic Histories, which connect Tigranokerta with the district of Arzanene. Thus, Arzan as the main city of this province is a natural candidate for the site of Tigranokerta in Arzanene. ${ }^{78}$ The city, which is located on the Garzan River at the foot of the Tauros and the Bitlis Pass, lay along one of the major long-distance lines of communication between Mesopotamia and Artaxata in ancient times. ${ }^{79}$ Sinclair's on-site examination made it clear that Arzan's topographical and geographical features and surroundings closely match the descriptions given by Plutarch and Arrian of the battle near Tigranokerta (see below). ${ }^{80}$ Additionally, a large number of coins of Tigranes the Great are reported to have come from this site. ${ }^{81}$

Three sites located south of the Tigris have been suggested as ancient Tigranokerta: Amida (modern Diyarbakir [ $\left.37^{\circ} 55^{\prime} 28.8^{\prime \prime} \mathrm{N}, 40^{\circ} 12^{\prime} 39.9^{\prime \prime} \mathrm{E}\right]$ ), Tell Abad [ $\left.37^{\circ} 25^{\prime} 0^{\prime \prime} \mathrm{N}, 41^{\circ} 22^{\prime} 11^{\prime \prime} \mathrm{E}\right]$ and, the most prominent, Tell Ermen (Kizltepe $\left[37^{\circ} 11^{\prime} 38^{\prime \prime}\right.$ $\left.\mathrm{N}, 40^{\circ} 35^{\prime} 10^{\prime \prime} \mathrm{E}\right]$ ) (Fig. 1).

The identification of modern Diyarbakır as ancient Tigranokerta is based on explicit literary evidence: Moses Khorenats' $i$, Elishē, and Matthew of Edessa. It seems to be an inherently Armenian tradition that has survived until modern times among the local Armenian population known as the Dikranagerdtsi ("natives of Dikranagerd" ${ }^{82}$ ). It was also accepted by some scholars in the 19th century: J. Saint-Martin, ${ }^{83}$ Ainsworth, ${ }^{84}$ and Macler. ${ }^{85}$ However, this identification is very peculiar: ${ }^{86}$ no other source puts Tigranokerta on the Tigris (which had been crossed by Lucullus' troops well before they reached the city). Further, it seems that it did not account for a considerable settlement in the 1st century BCE, as Amida was considerably

${ }^{78}$ The city name Arzan is based on Arzn, the name of the district. In turn, the Armenian province, Ałjnik' (Greek Arzanene), included several smaller districts between the Batman and Bohtan rivers. Arzn was the most well-known district in Ałjnik', and its name was sometimes used as a pars pro toto name for the whole province. The Greek and Latin forms, A $\rho \zeta \alpha v \eta v \eta$ and Arzanena, were coined after Arzn. See HÜBSCHMANN (n. 71) 248-251 (esp. 250), 305-306, 310-312; HEWSEN: Introduction IV (n. 4) 76-78 and SINCLAIR: Tigranocerta II (n. 3) 94 and n. 95.

${ }^{79}$ SINCLAIR: Tigranocerta II (n. 3) 93.

${ }^{80}$ In this sense, Sinclair's examination renders some of the topographical observations of the 19th and early 20th centuries CE outdated (e.g., see BELCK [n. 64] 267-268 and LEHMANN-HAUPT: Armenien [n. 71] 385 claiming that the vicinity of Arzan measures up poorly against the evidence of ancient topographical descriptions).

${ }^{81}$ Although this fact is not well documented. GUYER (n. 76) 207, n. 2, quotes the personal communication of Herzfeld, who, however, did not see the coins himself, but only heard of them. TAYLOR (n. 66) 27 indeed mentions a large number of gold and silver coins unearthed by locals at the site, but he does not give any details about them. See also DiLLEMANN (n. 3) 263.

${ }^{82}$ HovanNiSIAN, R.: Armenian Tigranakert/Diarbekir and Edessa/Urfa. In HovANNISIAN, R. G. (ed.): Armenian Tigranakert/Diarbekir and Edessa/Urfa [UCLA Armenian History and Culture Series 6]. Costa Mesa, California 2006, 1-46, here 1-2.

${ }^{83}$ SAINT-Martin, M. J.: Mémoires historiques et géographiques sur l'Arménie. T. 1. Paris 1818, $172-173$

${ }^{84}$ AINSWORTH, W.: Travels and Researches in Asia Minor, Mesopotamia, Chaldea, and Armenia. Vol. 2. London 1842, 362-363.

${ }^{85}$ MACLER (n. 56) 161.

${ }^{86}$ CHAumONT: Tigranocerte (n. 2) 100: “Cette tradition fallacieuse, dont il est malaisé de déceler l'origine... ". 
enlarged and militarily strengthened only in the 4th century CE by Emperor Constantius II. $^{87}$

Tell Abad (also called Tell Biat or Bejâd) was suggested as ancient Tigranokerta by H. C. Rawlinson. ${ }^{88}$ His identification was later supported by T. Mommsen (originally), ${ }^{89}$ H. Kiepert ${ }^{90}$ and T. Reinach (who actually meant the modern Midyat, ${ }^{91}$ less than $1 \mathrm{~km}$ south of Tell Abad). ${ }^{92}$ This is perhaps the least documented identification. The tell is indeed of considerable proportion, but there is no river in the vicinity, and the claim that a large hoard of Greek and Parthian coins was discovered in Tell Abad apparently resulted from a misunderstanding. ${ }^{93}$

Tell Ermen (Kizultepe) has always been the most significant candidate south of the Tigris for the location of Tigranokerta. More precisely, this suggestion includes the mound (Tell Ermen) and the site of the nearby city, Dunaysīr. It was first proposed by E. Sachau ${ }^{94}$ and has always had prominent supporters including T. Mommsen, ${ }^{95}$ B. Henderson, ${ }^{96}$ L. Dillemann, ${ }^{97}$ and F. Lasserre. ${ }^{98}$ The strongest argument in its favor is its correspondence with data from Strabo and Tacitus: it is located $65 \mathrm{~km}$ from Nisibis (approximately $10 \mathrm{~km}$ more than indicated in Tacitus' data ${ }^{99}$ ) and at the foot of a belt of limestone hills - the modern Țūr 'Abdīn and Mazi mountains (Strabo's Masion). Tell Ermen is also located at the crossroads of important lines of

${ }^{87}$ By contrast, some scholars (BELCK [n. 64] 267; HOLMES: The roman Republic [n. 2] 411; LEHMANN-HAUPT: Tigranocerta [n. 4] 984) put forward a different argument: it could not receive a different name from that which is otherwise well attested in Assyrian (Amid) and Roman times (Amida). This line of reasoning implies that the city must have been a well-known settlement in Tigranes II's times under the name Amida/Amit. However, there are no literary sources that could give any support to this claim. Whether or not there was a considerable settlement in the 1st century BCE at the site later known as Amida cannot be definitely settled without excavations, but Tigranes' foundation could be located at a place of earlier settlements, which was simply renamed. Today's most accepted identification of Tigranokerta as Arzan maintains something similar: it was founded at the place of the Assyrian Kullimeri / Ptolemy's Cholimma. What is more, according to Sinclair, its original name reappears as Chlomaron in Byzantine sources. See SINCLAIR: Tigranocerta II (n. 3) 94-108, esp. 94-99.

${ }^{88}$ Rawlinson, H. C.: Assyrian Discovery. The Athenaeum. Journal of Literature, Science, and the Fine Arts. January to June 1863, 228-229, here 228.

${ }^{89}$ Mommsen, T.: Die Lage von Tigranokerta. Hermes 9 (1875) 129-138, but see MOMMSEN, T.: Römische Geschichte. Bd. 3. Berlin $1909^{10}, 68$, where he opts for Tell Ermen.

${ }^{90}$ KIEPERT (n. 74) 142-149.

${ }^{91}$ HoLMES: The Roman Republic (n. 2) 410, n. 10 counts this identification as one of many "absurd and obsolete guesses".

92 REINACH, TH.: Mithradates Eupator, König von Pontos. Leipzig 1895, 342, n. 1

${ }^{93}$ See that Rawlinson relies on Taylor for this claim, but TAYLOR (n. 66) 35 himself admits that he only heard about such a discovery from locals. See also HoLMES: The Roman Republic (n. 2) 411 and CHAUMONT: Tigranocerte (n. 2) 100-101.

${ }^{94}$ SACHAU, E.: Über die Lage von Tigranokerta. Abhandlungen der Königlichen Akademie der Wissenschaften zu Berlin 1880, 3-92; SACHAU, E.: Reise in Syrien und Mesopotamien. Leipzig 1883, 403.

${ }^{95}$ MOMMSEN: Römische Geschichte (n. 89) 68 (with some hesitation concerning the Tigris crossing by Lucullus).

\footnotetext{
${ }^{96}$ HENDERSON (n. 1) 99-121.

${ }^{97}$ DiLLEMANN (n. 3) 247-272.

${ }^{98}$ LASSERRE (n. 6) 176-177.

${ }^{99}$ HOLMES: The Roman Republic (n. 2) 413.
} 
communication; it most likely functioned as a station along the Persian royal road. ${ }^{100}$ What is more, its topographical features also roughly match the most important requirements: the mound is of considerable proportion $(48 \mathrm{~m}$ high and $279 \mathrm{~m}$ long from east to west ${ }^{101}$ ), it is located on the Zergan River, there is an extensive plain on both sides of the river, and there would theoretically be room for Appian's parks, hunting-grounds, and lakes/pools. ${ }^{102}$

As far as Tigranokerta in northeastern Armenia is concerned, Sebēos' expression "the other Tigranokerta" (38. 125) is understood in two very different ways: either as suggesting that in addition to Tigranokerta (founded as the new capital by Tigranes the Great), there was yet another city bearing this name in northeastern Armenia, ${ }^{103}$ or that there were as many as two cities bearing this name on the route of Heraclius' troops, both located in northeastern Armenia. ${ }^{104}$ Sebēos' reference puts "the other Tigranokerta" in the Gardman district, which can be located in the mountains to the east of Lake Sevan (including the valley of the Shamkhor River), but the exact location of the city of Tigranokerta in the Gardman is unknown. ${ }^{105}$ Scholars who are in favor of the existence of another city named Tigranokerta in this region point to the local Armenian tradition (attested in the 19th century CE), which preserved names such as Tngrnakert, Tarnakert, Taraniurt, or Tarnagiurt in the vicinity of Shahbulagh. ${ }^{106}$ Following this tradition, the vicinity of Shahbulagh has been the scene of large-scale excavations by Armenian archaeologists since 2005 (still ongoing), which have revealed a massive settlement that was inhabited from the 1 st century BCE to the 14 th century CE. ${ }^{107}$ The findings include, among others, massive walls, a citadel, residential quarters, Hellenistic and early Christian necropolises, and a Christian basilica dating to the 5 th and 6 th centuries $\mathrm{CE}$. The main excavator, H. Petrosyan identified the Hellenistic settlement as the city called Tigranokerta and built by Tigranes the Great.

\section{RE-EVALUATION OF THE SCHOLARLY DISCUSSION}

Recent scholarship has been marked by four issues: the reinterpretation both of Strabo's geographical notions and of Tacitus' reference to the distance between

${ }^{100}$ DillemanN (n. 3) 248-250.

${ }^{101}$ SINCLAIR: Tigranocerta I (n. 4) 233.

${ }^{102}$ SACHAU: Über die Lage von Tigranokerta (n. 94) 78-82; SACHAU: Reise (n. 94) 402-403, 425; Holmes: The Roman Republic (n. 2) 412; DillemanN (n. 3) 254-256, 266-268.

${ }^{103}$ HÜBSCHMANN (n. 71) 473-474; CHAUMONT: Tigranocerte (n. 2) 108-109, who knew the idea of two Tigranokertas located in northeastern Armenia, but strongly opposed it.

${ }^{104}$ Hewsen: Armenia (n. 37) 58. Probably PeTROSYAN: Tigranakert (n. 4) 382 too, but he refers to Sebēos to back up his identification, which is unusual.

${ }^{105}$ HewSEN: The Geography (n. 56) 260-261; HewSEN: Armenia (n. 37) 58.

${ }^{106}$ HEWSEN: Armenia (n. 37) 58; PETROSYAN: Tigranakert (n. 4) 382.

${ }^{107}$ See PETROSYAN: Tigranakert (n. 4); PETROSYAN: La Tigranakert (n. 4). 
Nisibis and Tigranokerta, ${ }^{108}$ a new reading of the Silvan inscription, a meticulous onthe-spot re-examination of the city of Arzan and its vicinity by T. Sinclair, and finally the recent Armenian excavations near Shahbulagh.

Concerning Strabo's definition of Mt. Masion, it was already Lehmann-Haupt, who, being in favor of the site of Martyropolis, thought that Strabo's Masion could perhaps be understood as including the mountain range on either side of the Tigris: the Tauros (on its north bank) and the modern Țūr 'Abdīn and Mazi mountains (on its south bank). ${ }^{109}$ Indeed, Strabo's descriptions of Masion are a complicated matter. ${ }^{110}$ Namely, Strabo mostly puts Masion west of the Tigris in the region of Nisibis (11. 12. 4, 11. 14. 2, 16. 1. 23; likewise Ptolemy, Geog. 5. 17. 2), but he still considers it (wrongly) to be part of the Tauros. ${ }^{111}$ What is more, Strabo's detailed description of winter conditions on Mt. Masion in 11. 5. 6 (regular and heavy snowfalls, as well as the use of skis) does not match the region of the modern Țūr 'Abdīn and Mazi mountains; by contrast, it does correspond perfectly to winter conditions in the Tauros Mountain range east of the Tigris. This led R. Syme to give a slightly different solution to the problem of Strabo's Masion than the one suggested by Lehmann-Haupt. According to Syme, Strabo in fact knew only one mountain range between Armenia and Mesopotamia - the Tauros. As a result, a location at the foot of the Tauros (e.g., Martyropolis or Arzan) and a location at the foot of the Masion (e.g., Tell Ermen) is the same to Strabo. ${ }^{112}$

Another capstone of all identifications of Tigranokerta south of the Tigris is Tacitus' reference to the distance between Nisibis and Tigranokerta counted as 37 Roman miles. An emendation of 37 (septem et triginta) into 130 (centum et triginta) has been suggested, ${ }^{113}$ but there are no textual grounds for this step, which is clearly intended for achieving a certain historical interpretation. In turn, Markwart suggested that Tacitus borrowed this reference from a Greek source that counted the distance either in stathmoi or parasanges, and changed the unit of measurement (into miles) without re-calculating the distance. ${ }^{114}$ Sinclair, who also gave some arguments, recently suggested a similar idea. Namely, Sinclair pointed to two Arab geographers: Ibn al-Faqīh (10th century $\mathrm{CE}$ ) and Yãqūt (13th century $\mathrm{CE}$ ), who give exactly the same distance as Tacitus but between Nașībīn and Arzan and in parasanges.

${ }^{108}$ See CARCOPINO's words in (n. 69), which appear to be symptomatic of his times: "Pour moi, il m'est impossible de sacrificier les indications de Tac., Ann. XV, 4 et Strabo, XI, 12, 4 et XVI, 1, 23..." Remarkably, the times have changed.

${ }_{109}$ LEHMANN-HAUPT: Tigranocerta (n. 4) 997-999.

${ }^{110}$ See MARCIAK, M.: The Historical Geography of Gordyene. Part 1: Classical Sources. Anabasis. Studia Classica et Orientalia 3 (2012) 173-213, here 181-186.

${ }^{111}$ SYME: Anatolica (n. 4) 47-49.

112 Syme, R.: Tigranocerta. A Problem Misconceived. In BIRLEY, A. R. (ed.): Ronald Syme. Roman Papers. Oxford 1988, 245-251; SYME: Anatolica (n. 4) 47-49. Furthermore, SYME: Tigranocerta

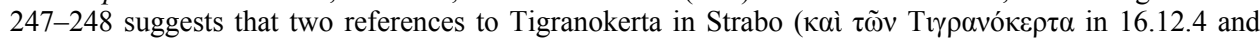

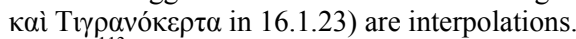

${ }^{113}$ Müller, C. - DüBnER, F.: Strabonis Geographica: Graece cum versione reficta. Vol. 2: Strabonis Geographicorum tabaulae XV. Paris 1858, 1019.

114 MARKWART (n. 50) 82-84. Likewise KOESTERMANN (n. 20) 169: “Anscheinend entstammt die falsche Angabe dem 'Urbericht'.' 
According to Ibn al-Faqīh, the distance between Nașībīn and Arzan is 37 farsākhs "on the right hand"; Yāqūt in turn repeats the same distance but adds "towards the west". 115 It is likely that the expressions "on the right hand" and "towards the west" can be seen as customary ways of formulating directions on a map, especially on the kind of ancient map we know from the Tabula Peutingeriana. Furthermore, Sinclair claims that Tacitus' reference to the distance between Nisibis and Tigranokerta is an interpolation. That is to say, the reference is, according to Sinclair, out of context in Tacitus' narrative about the Roman embassy sent to Vologaeses, the Parthian king at Nisibis: the embassy was not sent from Tigranokerta, and Tigranokerta could not have been on its route either, since the city was in Parthian hands then. All in all, Sinclair argues that Tacitus' reference is a medieval interpolation whose source was likely an ancient map (also used by the Arab geographers), which counted the distance between Arzan/Tigranokerta and Nisibis in parasanges. ${ }^{116}$

The discovery of an inscription commemorating the recapture of royal dominions by an anonymous king in the walls of Silvan has long been seen as a clinching argument for the identification of this site with Tigranokerta. ${ }^{117}$ However, the inscription was recently reinterpreted by $\mathrm{C}$. Mango. First, Mango dated the inscription to the 5 th or 6th century $\mathrm{CE}$ on paleographic grounds, and, more precisely, to the 6th century $\mathrm{CE}$ on the basis of its grammar and vocabulary. ${ }^{118}$ Secondly, according to Chaumont and Mango, the situation described in the inscription (an Oriental king gives thanks to "the gods" for regaining his dominion, i.e., Ałjnik", previously lost by treason; the king also mentions both the Romans, who helped him recover his kingdom, and the Persian king) fits the history of the Persian king, Khusrav II (who regained his kingdom from the rebels with the help of Emperor Maurice in 588-591 CE) better than that of the Armenian king, Pap (who with the help of the Romans regained some territories in 370-374 CE lost by his father Aršak III, 338-367 CE). ${ }^{119}$

Next, T. Sinclair conducted a meticulous on-site examination of the site of Arzan and thoroughly compared its results with the topography of Silvan and Tell Ermen. ${ }^{120}$ Perhaps one could still argue that all three sites have some common features matching the basic requirements: remains of considerable walls, ${ }^{121}$ a river, a great

115 SINCLAIR: Tigranocerta II (n. 3) 89-90.

116 SINCLAIR: Tigranocerta II (n. 3) 88-93.

${ }^{117}$ LEHMANN-HAUPT: Eine griechische Inschrift (n. 73) 497-520; LEHMANN-HAUPT: Armenien (n. 71) 410-419, 498-515; LEHMANN-HAUPT: Tigranocerta (n. 4) 1002-1003.

${ }_{118}$ Mango, C.: Deux études sur Byzance et la Perse sassanide. Travaux et Mémoires 9 (1985) 91-118, here 101-104. Likewise CHAUMONT: Tigranocerte (n. 2) 104.

${ }^{119}$ CHAUMONT: Tigranocerte (n. 2) 104-105, n. 94; MANGO (n. 118) 101-104. Furthermore, it was already MARKWART (n. 50) 124* who dated the inscription differently than Lehmann-Haupt to the 3rd century CE and interpreted it as witness to the reinstallment of the Armenian King Tiridates III by the Romans.

${ }^{120}$ Taylor's observations from his visit to the site in 1861-63 (published in TAYLOR [n. 66]) are still partly useful because of the devastation brought to the ruins since then (by "ploughing and agricultural activities" of the local population, see COMFORT [n. 77] 284-285).

${ }^{121}$ It is only in Tell Ermen that no wall remains can be detected on the surface. SACHAU: Über die Lage von Tigranokerta (n. 94) 79 tentatively suggested that the extent of pottery and masonry debris on the ground could match the circumference of city walls. 
plain by the river, and the location in the vicinity of mountains. ${ }^{122}$ However, in light of Sinclair's research, we can safely state that it is only the site of Arzan and its immediate vicinity that features several unique details, which cannot be said about Silvan or Tell Ermen. Namely, some $12 \mathrm{~km}$ upstream of Arzan there is a modern village Golamasya whose vicinity plays an important role in Sinclair's interpretation. It is just by Golamasya where the river is easiest to ford nowadays, ${ }^{123}$ and near the village there is a pool lined with flagstones which was identified by Sinclair as one of Tigran's $\lambda$ í $\mu v \alpha{ }^{124}$ Next, near the same village (southwest) there are ruins which could tentatively be interpreted as Tigran's $\beta \alpha \sigma i \hat{\lambda} \varepsilon 1 \alpha{ }^{125}$ Likewise, opposite Golamasya there arises a considerable flat-topped hill on the west bank of the Garzan River, nowadays called Zercel Kale, which could match the hill from which Lucullus rushed down at the Armenian army. ${ }^{126}$

Comparing the topography of Arzan and its vicinity with that of the other candidates, we must notice that both Silvan and Tell Ermen have definitely less to offer than Arzan. There are no remains in Silvan which suggest Tigran's fortress (outside the city walls), palace and $\lambda i \mu v \alpha$. In Tell Ermen, one could tentatively suggest Tigran's $\beta \alpha \sigma i ́ \lambda \varepsilon ı \alpha$ at Tell Harzem (matching an Achaemenid palace and Arcamo of TP) ${ }^{127}$ and perhaps Appian's fortress at the tell itself. If the latter is true, then the city would be located at the site of the medieval city of Dunaysin, although supporters of this location mostly point to the tell as the site of the city. ${ }^{128}$ Yet there are no remains of $\lambda i \mu v \alpha 1$ and there is no candidate for the hill that played an important role in Lucullus' tactics. Arzan is definitely the best candidate in terms of topographical features. Finally, the identification of the Nicephorius also points to Arzanene as the location of Tigranokerta. Namely, besides Tacitus, it is also Pliny who mentions this river (as Nicephorion) together with Parthenias as tributaries of the Tigris (Plin. HN 6. 129). ${ }^{129}$ Pliny's Parthenias is widely identified with the Batman. ${ }^{130}$ If this identification is

${ }^{122}$ Here we do not go into detail. For instance, SINCLAIR: Tigranocerta I (n. 4) 224 claims that the ditch and the city walls in Silvan, both of considerable proportions, must be the result of Byzantine or medieval building and engineering work (the existence of which we know from literary sources). Yet, this opinion cannot be definitely confirmed without excavations. After many centuries and exclusively on the basis of field surveys, any assessment concerning such features can only be tentative.

${ }^{123}$ SINCLAIR: Tigranocerta I (n. 4) 208.

124 SINCLAIR: Tigranocerta I (n. 4) 205.

125 SINCLAIR: Tigranocerta I (n. 4) 205-206.

126 SINCLAIR: Tigranocerta I (n. 4) 208.

127 DillemanN (n. 3) 159, 170.

${ }^{128}$ SINCLAIR: Tigranocerta I (n. 4) 237.

${ }^{129}$ Notice that the Zergan River (on the banks of which Tell Ermen is located) is a tributary of the Syrian Khabur (which is in turn a tributary of the Euphrates) and not of the Tigris.

${ }^{130}$ LEHMANN-HAUPT: Armenien (n. 71) 400; MARKWART (n. 50) 82, 121; HonigManN, E.: Die Ostgrenze des byzantinischen Reiches: von 363 bis 1071 nach griechischen, arabischen, syrischen und armenischen Quellen [Corpus Bruxellense Historiae Byzantinae 3]. Bruxelles 1935, 5; DILLEMANN (n. 3) 48-49, 253-254; BlOCKLEY, B. C.: The Romano-Persian Peace Treaties of AD 299 and 363. Florilegium 6 (1984) 28-49, here 31-32; WHEELER, E. L.: Rethinking the Upper Euphrates Frontier: Where Was the Western Border of Armenia?. In MAXFIELD, V. A. - DoBSON, M. J. (eds.): Roman Frontier Studies 1989: Proceedings of the XVth International Congress of Roman Frontier Studies. Exeter 1991, 505-511, here 506; 
correct, and if Pliny's reference (he mentions Parthenias and Nicephorion in a sequence) is geographically ordered (from west to east), then the Nicephorion should be the next major river east of the Batman. In this light, the Nicephorius/Nicephorion can only be the Garzan or, less likely, the Bohtan River. ${ }^{131}$

At the same time, one can see that the identification of Tigranokerta as Arzan continues to present challenges. Firstly, Pliny's expression in excelso does not fit Arzan well. ${ }^{132}$ Likewise, Sinclair's understanding of Arzan's topography implies Plutarch's major error in placing the battle scene on the east bank (instead of the west bank). ${ }^{133}$ And yet, this site matches the evidence of literary sources concerning the new capital of Tigranes the Great better than any other site suggested thus far.

Finally, another recent development in the discussion about ancient Tigranokerta has been provoked by the Armenian excavations in Artsakh. This issue is actually, so to speak, two-dimensional. First, it concerns the very identification of the site (by Hamlet Petrosyan); secondly, it also concerns potential consequences of this identification for our understanding of the urbanization policy of Tigranes the Great (and here the recent publications of Giusto Traina are particularly important ${ }^{134}$ ).

Concerning the identification of the site near Shahbulagh, a certain amount of caution is called for, as the excavations are not finished yet. ${ }^{135}$ However, to be able to unambiguously identify this settlement as one built by Tigranes the Great, an inscription would have to be found indicating the city's connection with Tigranes the Great, or at least a large hoard of coins struck on behalf of this king. Such evidence is lacking (for the time being, only silver drachmas of Parthian Mithradates III (58/57-54 BCE) and Orodes II (58/57-38/37 BCE) have been unearthed), and the current hypothesis is a highly speculative construction based on three premises: the 19th-century-CE Armenian local tradition, a connection between this site and Tigranokerta recalled by Sebēos and Stephen of Tarōn, and finally the dating of the site to the 1st century BCE. All these premises are questionable.

Firstly, as far as the 19th-century-CE Armenian local tradition is concerned, let us recall the case of Roman Amida - at least three Armenian sources (Moses Khorenats'i, Elishē, and Matthew of Edessa) perceived this city as Tigranokerta built exactly by Tigranes the Great. This evidence has never been taken seriously by schol-

TALBERT, R. J. A.: Barrington Atlas of the Greek and Roman World. Vol. I: Map-by-Map Directory. Princeton 2000, 1277; KAEGI, W. E.: Heraclius, Emperor of Byzantium. Cambridge 2003, 131; MARCIAK (n. 110$) 194$.

${ }^{131}$ Whitby, M.: Arzanene in the Late Sixth Century. In Mitchell, S. (ed.): Armies and Frontiers in Roman and Byzantine Anatolia [BAR International Series 156]. Oxford 1983, 205-218, here 217; HEWSEN: Introduction IV (n. 4) 7; and finally SINCLAIR: Tigranocerta I (n. 4) 203.

${ }^{132}$ SINCLAIR: Tigranocerta I (n. 4) 212 suggests that Pliny's expression may mistakenly refer to the nearby Zercel Kale.

${ }^{133}$ SINCLAIR: Tigranocerta I (n. 4) 209-210; SINCLAIR: Tigranocerta II (n. 3) 109.

134 TrainA: Strabone (n. 4); TRAINA, G.: Roman perceptions of Caucasian Albania. In SIMONYAN, A. (ed.): Republic of Nagorno-Karabakh: Past, Present and Future. International Scientific Conference (Stepanakert, 21-24 giugno 2006). University Press, Erevan 2007, 223-228 and TRAINA: Capitales (n. 4) in particular.

${ }^{135}$ It is also important to note the strongly political context of the excavations located on the territory of the internationally unrecognized Nagorno-Karabakh Republic. The present description is based on PETROSYAN: Tigranakert (n. 4); PETROSYAN: La Tigranakert (n. 4). 
ars, because there is other strong evidence, both literary and topographic, that the new capital of Tigranes II lay elsewhere. Yet this either suggests that at some point in its history a site like Amida could have been renamed by an Armenian or Parthian king bearing this name, or (more likely) that cities of considerable proportions and political significance could have become a Tigranokerta in folklore. The last option should warn us against all attempts to identify ancient Armenian cities based mainly on the local tradition of the 19th century.

Secondly, concerning the connection with another Tigranokerta in northeastern Armenia mentioned by Sebēos and Stephen of Tarōn, neither of these writers linked this Tigranokerta with Tigranes the Great. They could therefore be foundations of Tigranes I or other Armenian or Parthian kings named Tigranes. This alone could suggest as many as five Armenian kings as its founders: Tigranes I (before $95 \mathrm{BCE}$ ), Tigranes II (95-55 BCE), Tigranes III (20-8/6 BCE), Tigranes IV (8-5 BCE and 2 BCE-1 CE), and Tigranes V $(6-14 \mathrm{CE}){ }^{136}$

Thirdly, if this site is to be called Tigranokerta at all, and some parts of the settlement (which is not wholly uncovered yet) are to be dated to the early 1 st century BCE, then the primary foundation of the city by Tigranes I (the father of Tigranes the Great) can also come into play.

All in all, Petrosyan's site must have been a city of high importance, as demonstrated by the impressive scale of this settlement and the character of Hellenistic finds, but this fact itself does not entail any specific identification.

Another important issue connected with the identification of the site near Shahbulagh was raised by G. Traina. In short, Traina accepted Petrosyan's identification of the site as Tigranokerta built by Tigranes II (the Great) - of course, not as the new capital of Tigranes the Great but as yet another city bearing the name of its founder, Tigranes the Great. What is more, Traina suggests that the existence of this city in the region between Armenia and Iberia explains well one extremely curious passage from

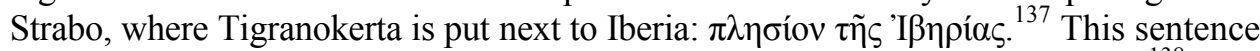
has been emanated in many ways, but Traina now suggests taking it literally. ${ }^{138}$ This suggestion may open a new perspective - there were more than one Armenian city

\footnotetext{
${ }^{136}$ GarsoÏAn, N. G.: The Emergence of Armenia. In Hovannisian, R. (ed.): The Armenian People from Ancient to Modern Times. Vol. I: The Dynastic Periods: From Antiquity to the Fourteenth Century. London - New York 1997, 37-62, here 62.

${ }^{137}$ Likewise tentatively CHAUMONT: Tigranocerte (n. 2) 109. Many other scholars preferred to emendate this reference. The following emendations have been suggested (see CHAUMONT: Tigranocerte

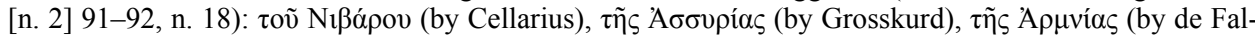

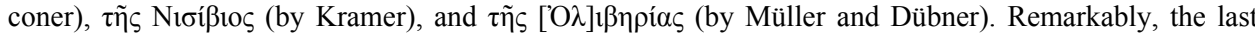
emendation leads to the identification of Tigranokerta with Edessa, since $\mathrm{O} \lambda \mathrm{i} \beta \eta \rho \alpha$ was located by

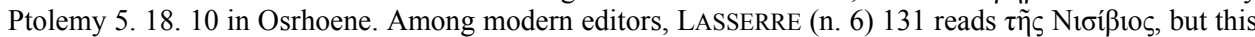
reading is rejected by RADT: Strabons Geographika Bd. 7 (n. 7) 329 as a "Randbemerkung eines Lesers". Radt otherwise remains undecided. See also DillemanN (n. 3) 255-256, who saw a possibility that the text may reflect of another Tigranokerta in northeastern Armenia, but finally rejected this idea.

${ }^{138}$ TRAINA: Roman perceptions (n. 134) 225-226.
} 
foundations called Tigranokerta and founded by Tigranes the Great, ${ }^{139}$ and it is also anachronistic to speak of only one capital of Tigranes the Great, as, in accordance with Armenian customs, there were many royal residences which were occasionally used by the king, who otherwise spent his time in the royal camp. ${ }^{140}$ Furthermore, the fact that the existence of at least one Tigranokerta in northeastern Armenia led to some confusion in ancient transmission may suggest that some other features ascribed to Tigranokerta and perceived by scholars as irregularities may have the same source the existence of other cities bearing this name. ${ }^{141}$

However, tempting as Traina's suggestion may appear, there are two problems with this theory. Firstly, separate premises cannot sustain the weight of the whole theory: Petrosyan's identification is not based on solid grounds; what is more, one may wonder if Strabo should really be understood as having had two Tigranokertas in mind. On the contrary, Strabo always characterizes Tigranokerta either as the new capital of Tigranes II or as lying in the vicinity of Mt. Masion. The two features do not exclude each other, but in fact go hand in hand. One, apparently corrupted, term in Str. 11. 14. 15 does not change anything in this respect - Strabo knows only one Tigranokerta. Secondly, there is also a chronological problem: one needs to take account of the chronological context of our sources, and virtually every source knows of only one Tigranokerta. Only Sebēos in the 7th century CE is likely to have had the knowledge of two cities bearing the same name. The sources from the 1 st and 2 nd centuries CE (Strabo, Plutarch, Tacitus, Appian, Pliny the Elder, and Ptolemy) do not know of two Tigranokertas. Special attention should be given to Ptolemy, because he provides us with detailed lists of cities in this region of the Near East in the 2nd century CE. Remarkably, Ptolemy knows of two other settlements which bore similar names to

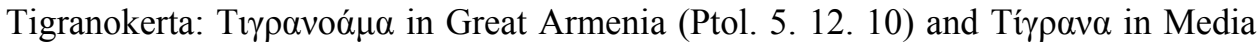
Atropatene (Ptol. 6. 2. 9); yet he knows of only one Tigranokerta.

${ }^{139}$ Likewise HoLmes: The Roman Republic (n. 2) 424, who once wrote: "May I tentatively suggest that just as one Nicopolis is represented by Niboli and another by Purkh, just as Tash Keupsi arose out of one Pompeiopolis and Mezetli out of another, so the Tigranocerta ...",139

140 TRAINA: Capitales (n. 4) 45-49.

141 Another curious passage in ancient sources which was tentatively taken as a hint at another Tigranokerta in northeastern Armenia is Appian Mithr. 67, who writes that Tigranes the Great founded his new capital at the very spot where he had first assumed the royal diadem. It has been argued (CHAUMONT: Tigranocerte [n. 2] 89, 105, 109) that no location in the Upper Tigris region or Mesopotamia could match this data, as neither area belonged to his realm at that time. However, we do not know which route Tigranes took from Lower Mesopotamia (where he resided as a hostage) to Artaxata (see GELLER, M. TRAINA, G.: Tigranu, the Crown Prince of Armenia: Evidence from the Babylonian Astronomical Diaries. Klio 95 [2013] 447-454). In fact, as Tigranes II succeeded to the Armenian throne with the help of the Parthian King Mithradates II (122-87 BCE), he may have assumed the diadem on his way back from the Parthian court, perhaps not far from Armenian soil but still on what was Parthian territory at that time. If so, this could actually mean any site in the Upper Tigris region. 


\section{CONCLUSIONS}

1. Richard Holmes, a respected historian of ancient Rome, wrote in 1923: "The contradiction between the statements of Strabo and Tacitus on one side and of Pliny, Eutropius, and Faustus on the other has never been explained ...". ${ }^{142}$ Nowadays, we believe we know what made Strabo's and Tacitus' references lead us astray. Consequently, the possibility for Tigranokerta to be located in the Nisibis region as the new capital of Tigranes the Great has been reduced to a minimum.

2. There can only be one Tigranokerta founded by Tigranes the Great (Tigranes II) as the new capital of his kingdom: it was most likely located in Arzanene, and probably at the site of today's Arzan. ${ }^{143}$ Both literary evidence and field surveys speak in favor of this identification.

3. All sources from the 1st and 2nd centuries CE know of only one city-foundation called Tigranokerta (and founded by Tigranes the Great), and there is no evidence that any other city bore the same name at that time. There was indeed at least one city named Tigranokerta in northeastern Armenia, but it is attested only in the 7th century CE.

4. There is no tangible evidence (yet) to back up Petrosyan's identification of the site near Shahbulagh as the city called Tigranokerta and founded by Tigranes the Great. The impressive scale of this settlement and the character of Hellenistic finds suggest that it was a city of high importance, but this fact alone does not imply a specific identification.

Michal Marciak

Ancient History and Oriental Studies

University of Rzeszów

Rejtana 16c

35-959 Rzeszów

Poland

${ }^{142}$ Holmes: The Roman Republic (n. 2) 424.
${ }^{143}$ Likewise TRAINA: Teatro greco (n. 77) 99. 

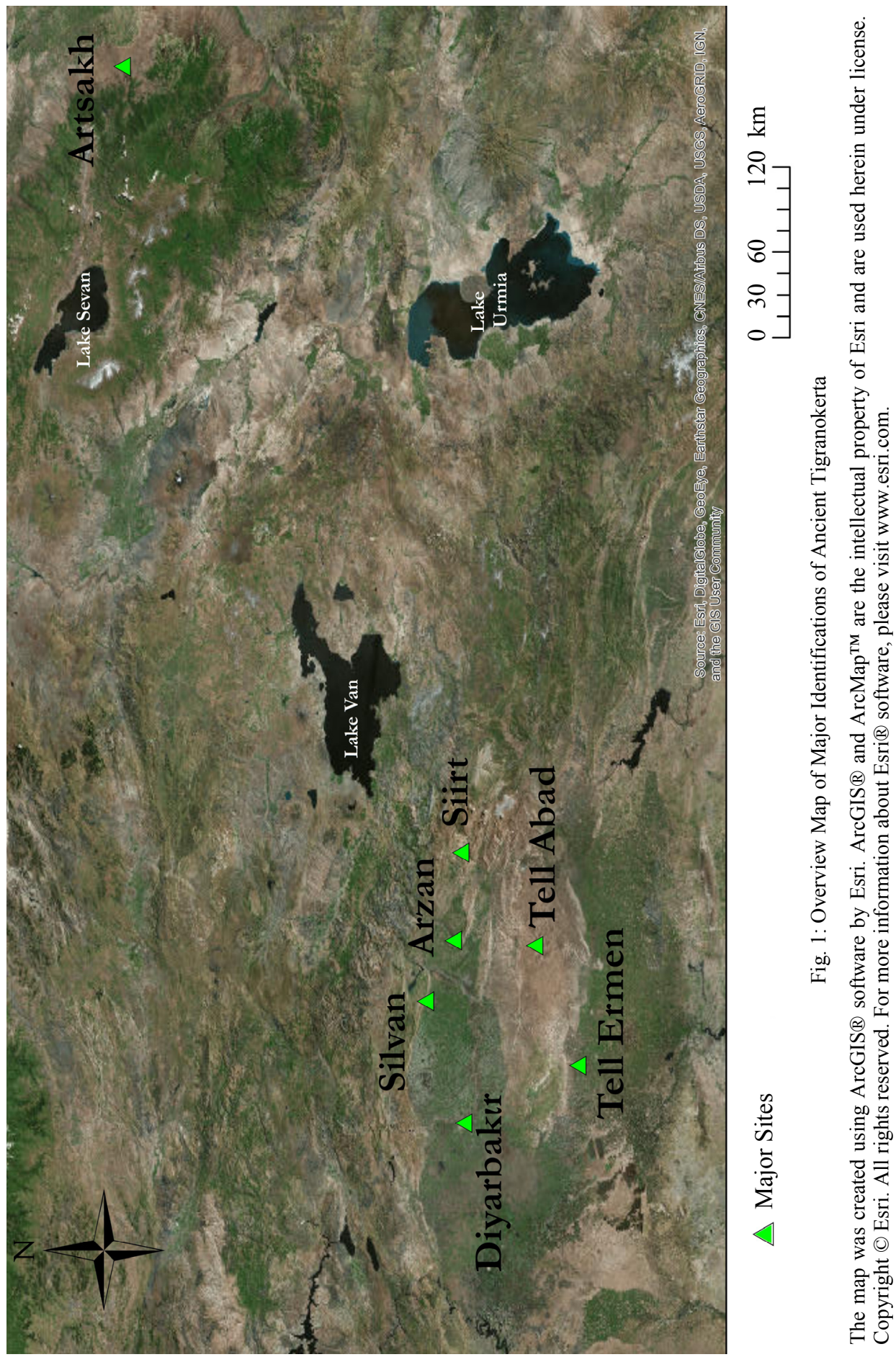

Acta Ant. Hung. 56, 2016 